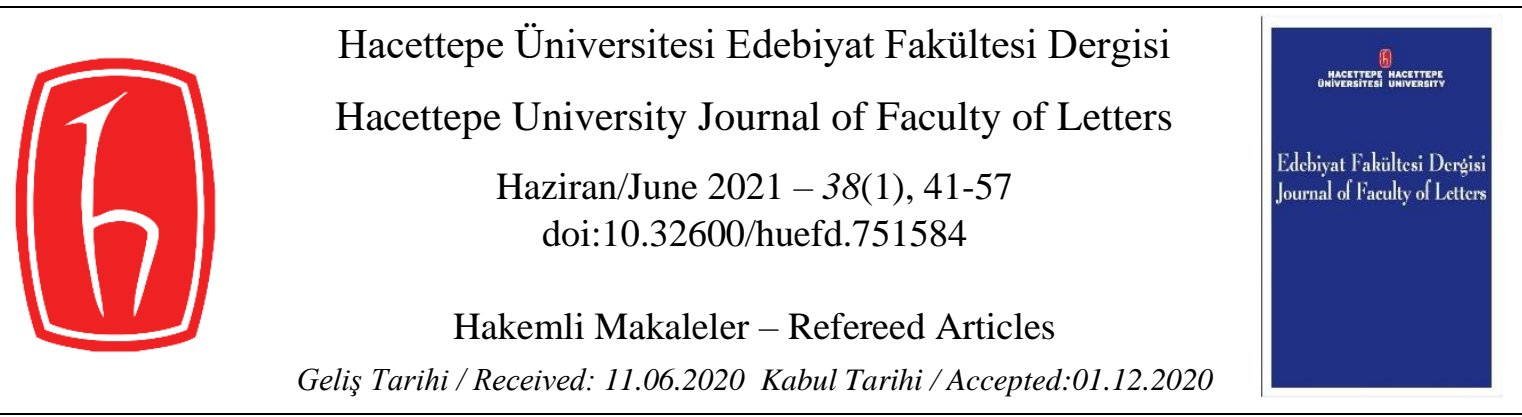

\title{
Türkiye’de “Tele Çalışma” Üzerine Sosyolojik Bir Değerlendirme: Gölge Çalışanlar
}

\author{
A Sociological Evaluation on "Tele Working” in Turkey: Shadow Employees
}

\author{
Canan GÖNÜLLÜ*
}

\begin{abstract}
$\ddot{\mathbf{O} z}$
Gelişen teknoloji ve dönüşen dünya ile birlikte çalışma şartları ve koşullarında da çeşitli değişiklikler göze çarpmaktadır. Üretim ilişki ve biçimlerinin değişmesi, tarihsel süreç içinde çalışmanın niteliğini değiştirirken, bilişim teknolojilerinde ve üretim araçlarında meydana gelen değişim ve dönüşümler de klasik çalışma yöntem ve biçimleri üzerinde birtakım etkilere ve değişimlere sebep olmuştur ve olmaya devam etmektedir.

Günümüz bilgi toplumlarında, üretimin kas gücünün ötesine geçmesiyle birlikte tele-çalışma adı verilen çalışma biçimi de gündeme gelmiştir ve görülme sıklığı giderek artmaktadır. Çalışanların zaman ve mekândan bağımsız olarak çalışmasına imkân veren bu anlayış, toplumsal birtakım tartışmaları da beraberinde getirmektedir.

Bu çalışmada yaygınlığı giderek artmakta olan çalışma biçimlerinden tele çalışmanın, çalışanlar üzerindeki etkileri çok yönlü olarak incelenmiştir. Bu çalışma biçiminin bireysel ve toplumsal yansımaları sosyolojik bir perspektifle ele alınmıştır. Nitel olarak tasarlanan bu çalışmada, tele çalışma biçimiyle çalışma yaşantısında yer alan kişilerle derinlemesine mülakatlar yapılmıştır. Görüşülenlerin seçilmesi amaçlı örnekleme biçimlerinden olan kartopu örneklemesi ile gerçekleştirilmiştir. Verilerin çözümlenmesi için içerik analizi tekniğinden faydalanılmıştır. Çalışma sonundaki bulgular, bu yeni çalışma biçiminin toplumda kabul görmesinin, sürece yayılması gerektiği ile paralellik göstermektedir. Ayrıca bu çalı̧̧ma biçiminde sosyal bir varlık olarak insanın sosyal yönünün, çalışan olarak dikkate alınması gerektiği sonucuna ulaşılmıştır.
\end{abstract}

Anahtar sözcükler: Home-Office, tele çalışma, esnek çalışma biçimleri.

\begin{abstract}
With the developing technology and transforming world, various changes in working conditions and conditions are also noticeable. While the changes in production relations and forms have changed the quality of work in the historical process, the changes and transformations in information technologies and production tools have caused and continue to have some effects and changes on classical working methods and forms.

In today's information societies, as the production goes beyond muscle strength, the so-called teleworking method has come to the agenda and its frequency is increasing. This understanding, which allows employees to work independently of time and space, brings with it some social debates.

In this study, the effects of working on telework, which is becoming more widespread, on employees, have been examined in many ways. The individual and social reflections of this form of work are handled from a sociological perspective. In this qualitatively designed study, in-depth interviews were made with people working with teleworking. It was carried out with the snowball sampling, which is one of the sampling forms for selecting the interviewees. Content analysis technique was used to analyze the data. Findings at the end of the study show that
\end{abstract}

* Dr. Öğr. Üyesi., Mehmet Akif Ersoy Üniversitesi, Fen-Edebiyat Fakültesi, Sosyoloji Bölümü, cgonullu@mehmetakif.edu.tr, ORCID: 0000-0002-7387-1718 
the acceptance of this new form of work in society should spread to the process. In addition, it was concluded that the social aspect of the human being as a social asset should be taken into account as an employee in this form of work.

Keywords: Home-Office, telework, flexible ways of working.

\section{Giriș}

Gelişen teknoloji ve sistemler, özellikle enformasyon sistemlerinde meydana gelen değişmeler, ekonomi alanında da köklü değişmelere sebebiyet vermektedir. İnternetin ticaret uygulamalarında yaygın kullanımı, internetin belirleyici bir faktör olarak mal ve hizmetlerin küresel boyutlarda dağıtımını ortak kılmakla birlikte e-ticaret adı verilen konunun da gündeme gelmesine sebep olmuştur. Dolayısıyla ekonomiler, endüstri yapıları, ürün ve hizmetler ile bu ürün ve hizmetlerin akışı, tüketici değer ve davranışları, en nihayetinde meslekler ve emek pazarları da neredeyse tamamen değişmiştir. Değişen bu yapı toplumlarda, politikalarda ve hatta bireylerin dünyaya ve kendilerine bakış açılarında bile büyük farklılıklara da etki etmiştir (Drucker, 2001, s. 41). Bu değişmelerin en büyük yansıması kuşkusuz çalışma biçimlerinde gözlemlenmektedir.

Sanayi Devrimi öncesinde doğal bir yaşam sürmekte olan, endüstrileşme ve makinelerin etkin kullanımıyla birlikte ev ve iş yaşamı arasında sıkışıp kalan insanoğlu, insanlığın başlangıcından bu yana varlığını devam ettirebilmek adına sürekli çalışmıştır. Sanayi Devrimi’nden önce insanlar çoğunlukla kendi tarlalarını ekip biçerken ve buradan elde ettiği ürünleri tüketerek hayatına devam ediyorken, insanlığı derinden etkileyen Sanayi Devrimi sonrası makinelere bağımlı hale gelerek hayatını kaçınılmaz olarak yeni gelişmelerin beraberinde getirmiş olduğu bu yeni işleyişe göre planlama yolunu seçmiştir. Kısaca insanlığın, Sanayi Devrimi ile birlikte, doğal bir hayattan suni bir hayata geçiş yaptığını ve çalışma kavramının da bu yeni çalışma biçimine uygun olarak yeniden tanımlanmak zorunda kaldığını söylemek mümkündür (Watson, 2004, s. 1).

Esnekliğin ortaya çıkışının birtakım yapısal değişiklikler sonucu 1970'lerden sonra gerçekleşmeye başladığı düşünülmektedir. Ulusal ve uluslararası rekabet şartlarının bu dönemlerde eskiye nazaran artış göstermesi, teknikteki ve ekonomik açıdan meydana gelen zorlukların baş göstermesi ve bunlarla birlikte sosyal durumunda değişmesi konuyu yakından ilgilendirmektedir (Baykal, 2003, s. 9-10). Bu gelişmelerle birlikte; evden çalışma, ev merkezli çalışma gibi farklı isimlerle tanımlanmaya çalışılan ve bilişim teknolojilerinin kullanıldığ iş alanlarında ve mekân olarak çalışanın evinin kullanıldığı çalışmayı nitelediği için tele çalışma kavramı ön plana çıkarılmıştır.

Tele çalışma kavramı ortaya çıktığı şekliyle; iş etkinliklerinin büyük bir kısmını içeren esnek bir çalışma tarzı (Aksoy, 2012, s. 404) olarak tanımlansa da ekonomik yönünün yanı sıra sosyal boyutu da olan bir olgudur. Çalışanların iş ortamlarının düzenlenmesi gibi konular literatürde kendisine tartışma alanı bulunuyorken; iş ortamının aynı zamanda yaşam ve dinlenme alanı olması da beraberinde birçok durumun ortaya çıkmasına sebep olmaktadır. Çalışanların, işyerlerini sadece çalışma ortamı olarak değil; aynı zamanda sosyalizasyon sürecinin bir parçası olarak algıllyor olmalarından dolayı, evde çalışmanın iş motivasyonuna, ekip ruhuna, sosyalleşme ve çok yönlü olarak iş yerlerine ve çalışanlara ekonomik etkisine kadar pek çok konu gündeme gelebilmektedir.

Bu çalışmada ortaya çıktığı ve son halini aldığı şekliyle çalışma olgusunun günümüzdeki son hallerinden biri olan tele çalışmanın incelenmesi amaçlanmıştır. Tele çalışma olarak nitelendirilen çalışma biçiminin aynı zamanda "beyaz yakalılar"ın bir eylemi olduğunu da hatırlatmakta fayda vardır. Özellikle çalışmanın üzerinde yoğunlaştığı bilişim sektöründe tele çalışma yöntemiyle çalışanların uzaktan çalışma şartlarına uyum sağlayan görece eğitimli bireylerden oluştuğu dikkate değer konulardan biridir. Bu çalışma biçiminin "tam zamanlı" olarak içinde yer alan çalışanların sosyolojik değerlendirilmesinin yapılması önem arz etmektedir. Bu bağlamda çalışmanın Türkiye'de görülmeye başlayan çalışma biçimlerinden tele çalışma hakkında; çalışanlar üzerinden ortaya çıkan durumlarla ilgili bir fikir vermesi, konuyla ilgilenenlere 1şı tutması ve bu yeni çalışma biçimiyle ilgili literatüre katkı sağlayabilmesi umulmaktadır.

\section{Çalışma Olgusunun Özellikleri ve Değişen Şekli}

Çalışmanın hem olumlu hem de olumsuz özelliklerinin olduğu bilinmektedir. Şöyle ki; çalışma hayatı sosyal bir varlık olan insanın hayatının büyük kısmını kapsayan bir eylemdir. Bireylerin 
toplumdaki konumlarının belirlenmesinde çalışmanın büyük etkisi bulunmaktadır. Yani çalışma olgusunun bu yönüyle kişiye statü, ekonomik bağımsızlık ve dini özgürlük kazandırdığı, kişilerin potansiyellerinin harekete geçirilmesinde bir itici güç olduğu söylenebilmektedir. Ancak diğer taraftan çalışmaya yönelik eylemler, hem fiziksel hem de zihinsel yorgunluğu, bitkinliği, tükenmişliği de beraberinde getirebilmektedir (Grint, 1998, s. 1). Konuya bu açıdan bakıldığında ise çalışmanın sosyal yönünün ağır basması ve bireylerin kurduğu ilişkilerden ilişki biçimlerine kadar etkili olması göz önünde bulundurulduğunda çalışma kavramının sosyolojinin ilgi alanına girdiği de rahatlıkla söylenebilmektedir (Savc1, 1999, s. 150). Bu çalışmanın özgünlüğü tam olarak bu noktada ortaya çıkmaktadır. Aynı zamanda sosyal statü, iş ilişkileri gibi alanlar dikkate alındığında tele çalışma biçiminin ayrıca incelenmesi gerekmektedir.

Sanayi Devrimi'nden sonra baş döndürücü bir gelişim sürecinden bahsetmek mümkündür. Dönemin önemli özelliklerinden biri, kas gücünün yerini zihin gücünün almaya başlaması olmuştur. Kullanıcısı tarafından kontrol edilebilen ve programlar sayesinde çalışan bilgisayarların üretilmeye ve yaygınlaştırılmaya başlaması bu gelişmedeki en önemli faktörlerden biridir (Feenberg, 1990, ss. 709710). Bu noktada işleri artık insanlar yerine makinelerin yapmaya başlaması yeni bir dönüşümü ve tartışmaları da beraberinde getirmiştir.

\section{Post Fordizmin ve Yeni Biçimleri}

Fordizm'den sonra esneklik yaklaşımı gündeme gelmiştir. "Fordizmin Krizi" olarak anılan bu süreçte, yeni bir dönüşüm gerçekleşmiş ve süreç bir çeşit uyarlama mekanizması olarak nitelendirilmiştir (Ongan, 2004, s. 123). Teknolojinin hızla değişmesi ve farklı iş kollarının da ortaya çıkmaya başlamasından dolayı yeni bir dönüşüm sürecine girilmiş ve bu nedenle de yeni arayışlar baş göstermeye başlamıştır.

1970'lerde başlayan ve üretim sistemlerinde meydana gelen bu değişmeler, önceleri Neo-Fordizm olarak adlandırılmıştır. 80'lerin ortalarından itibaren yeni bir esneklik anlayışının geliş̧mesi ile ve işletmeler arasında kurulmaya başlanan network olarak tanımlanan yeni ağ ilişkilerinin ortaya çıkmasıyla birlikte Post-Fordizm kuramı gündeme gelmiştir. Kitlesel üretim ve tüketimin esnek talep ve esnek pazar koşullarına doğru evrilmesiyle birlikte sıfır stokla çalışma, sıfır hatalı üretim, tam zamanda üretim (just in time) gibi anlayışlar geçerlilik kazanmaya başlamıştır. Bu dönüşümün geçirdiği süreç, fordist üretimden esnek üretime geçiş olarak tanımlanmıştır (Şen, 2000, s. 25).

Esneklikle ilgili tanımlamalar göz önünde bulundurulduğunda, birbirlerinden farklı olmakla birlikte, genel olarak aşağıdaki özellikleri yapılan vurgu görülebilmektedir (Yalınpala, 2003, s. 277).

- İstikrarsız durumlarda, çalışma saatlerinin ve işgücünün istikrarsızlığa göre uyarlanması,

- Çalışanlara yapılan ödemelerin, piyasa talebine göre uyarlanması ve ücretlerin bu bağlamda yeniden düzenlenmesi,

- Çeşitli sorunlara karşı bir sistemin ya da alt sistemin uyum gösterebilme yeteneği,

- Hızlı değişiklik bağlamında bir zorunluluk ve hatta değiş̧ebilme yeteneği,

- Kurumsal, kültürel, sosyal ya da ekonomik düzenlenmelerin, değişikliklere uyum sağlama kapasitesini sürekli artıran uygulamalara göre değiştirilmesi.

Enformasyon teknolojilerine dayanan yeni örgütlenme biçimi, beraberinde işle ilgili olarak belirli amaçların değişmesi gibi bir durumu da getirmiştir. Yönetimin merkeziyetçilikten uzaklaşması ya da çalışmanın daha bireysel hale gelmesi bu durumların örneklerindendir. Aynı zamanda piyasaların artık siparişe bağlanması durumu da dikkat çekmektedir. Tüm bu sebeplerden dolayı çalışma parçalanmış ve geniş perspektiften bakıldığında da bu anlamda toplumlar parçalanmaya başlamıştır. Yeni enformasyon teknolojilerinin aktif kullanılmaya başlanmasıyla birlikte, görevler merkezden daha özerk şekilde yerine getirilebilir hale gelmiştir. Bahsi geçen görevlerin gerçek zamanda kıtalar arası ya da bir binanın farklı katlarında olmaksızın interaktif şekilde ve bir iletişim ağı içinde koordine edilmesi durumu sıkça gözlemlenmeye başlamıştır. Bu noktada destekli üretim yöntemlerinden de bahsedilebilmektedir. $\mathrm{Bu}$ yöntemle, işler sözleşmeli bir biçimde başka bir kola, şirkete devredilebilmekte ya da yurtdışında yaptırılabilmektedir. Yine aynı yöntemle, danışmanlıklar alınabilmekte, şirketin çapı küçültülebilmekte ya da siparişe bağlı işlerin yapılması gibi pratikler de görülmeye başlanmıştır (Castells; 2005, s. 357). 
Bu durumda şirketler, işçileri sürekli istihdam etmemekte ve gerektiğinde kısmi istihdam sağlamakta ya da sözleşme karşılığ 1 işi yaptırmaktadır.

$\mathrm{Bu}$ açıdan bakıldığında yeni işçi sınıfı olarak tabir edilen çalışanların; eğitimli emek olduğu söylenebilmektedir. Bu çalışanların görece daha iyi ücretler aldığı, bir ölçüde çeşitli ayrıcalıklara sahip olduğu bilinmektedir. Bu durum, emeğin değersizleşmesi tartışmalarını beraberinde getirmektedir. Günümüz gelişmelerine bakıldığında, henüz yakın zamanlarda ortaya çıkmış ve yaygınlaşmaya başlamış olan mesleklerin de emeğin değersizleşmesinden payını aldığı görülebilmektedir (Braverman, 2008, ss. 55-56). Eski zamanlardan bu yana kol emeğinden ziyade bir 'kafa' işi olarak kabul gören ve daha çok beyaz yakalı olarak adlandırılan sınıfın alanı olan büro işlerinde de mavi yakalılarda olduğu gibi bir rutinleşme, parçalanma ve vasıfsızlaşmadan söz edilebilmektedir (Kumar, 2004, s. 33).

\section{Tele Çalışma}

Yeni teknolojilerin üretimde kullanılmaya başlamasıyla birlikte, meydana gelen değişimler ele alınırken şu 3 durum göz önünde bulundurulmalıdır (Jackson, 1999, ss. 6-7);

- Teknolojideki yeniliklerin iş yapılanmaları üzerinde de etkili olduğunu görüp yeni olanakları anlayabilmek,

- Yeni yapılanma içinde ürünlerin, çalışma biçimlerinin, yapının, bilginin kullanımı ve yönetiminin ilerlemesini sağlayabilmek adına örgütsel tasarımın ve iş süreçlerinin de yeninden biçimlendirilmesi gerektiğini kavrayabilmek,

- Yeni oluşan durum özelinde düşünüldüğünde de tutum, değer, kavram ve teori değişikliklerinin yanında, yeni dinamikleri de anlama ve yönetme pratikleri geliştirebilmek.

Pek çok şirket çalışanları, yapmış oldukları iş mekânlarında esnekliğe imkân veren uygulamaların hem işin uygulanması aşamasında hem de aile ve özel hayatları arasında etkili bir denge kurabildikleri gerekçesiyle olumlamaktadır. Örneğin ABD'de şirketlerin yarısından fazlası (\%55) çalışanlarına esnek uygulamalar sağlayabilmektedir. Bu esneklik ara sıra evde çalışmaya müsaade etmek şeklinde olabildiği gibi düzenli olarak kuruluş dışında çalıştırma şeklinde de olabilmektedir. Oranlar incelendiğinde her 5 çalışandan 1'nin düzenli iş saatlerini evde geçirmekte olduğu görülmektedir (Hill v.d., 2003, s. 221). Amerika' da çalışanlara sağlanan haftanın belirli günlerinde işlerini evden gerçekleştirebilme imkânının da çalışanlar üzerinde sosyal etkileri üzerinde durulması gereken önemli noktalardan biridir. Çalışmanın ilerleyen bölümlerinde bu konuya yeniden değinilecektir.

Klasik anlamıyla evde çalışma kavramı, fazla nitelik gerektirmeyen daha çok el emeğiyle hazırlanan ve el becerisine dayanan işleri ifade etmektedir (Yavuz, 1995, s. 60). Tele çalışmada ise, yüksek nitelikler gerektiren işler anlaşılmalıdır çünkü bu çalışma biçimi daha çok bilgi ve iletişim teknolojilerinin kullanılmasını gerektirmektedir. Bu sebeple, işletmeye (hat-üstü olarak literatüre kazandırılmış) 'online' bağlantı söz konusudur. Ancak hat-dışı olarak nitelendirilebilecek ve daha çok offline olarak kullanılan şekilde de bağlantı sağlanabilmektedir (Blomeyer, 1994, s. 206). Çalışanlar böylece, söz konusu olan işin çıktılarını, bağlantılar aracılığıyla bağlı bulundukları yerlere gönderebilmektedir. Klasik anlamıyla kullanılan evde çalışmada ise böyle bir imkân kullanılamamakta ve işçiler genellikle önceden belirlenmiş olan işleri, iş yeri dışında gerçekleştiriyor olsalar da hat üzerinden teslimat söz konusu değildir (Hueck, 1994, s. 199). Tele çalışmanın evden çalışmadan ayrılan en önemli durumlarından biri; bazı zamanlarda işi gerçekleştiren kişiler ile müşterilerin ya da şirketin çeşitli kademelerinde yer alan yöneticilerin birbirlerini hiç görmemeleri durumunun yaşanabilmesidir.

Bilgi ekonomisinin içinde bir çalışanın; istihdam edilebilmesi ve ayrıca gelirini güvence altına alabilmesi için aynı zamanda da bir işten başka bir işe kolayca geçebilmesi için yeterli becerilere haiz bireyler olmaları gerekmektedir. Firmalar bu sektör için özellikle görece az sayıda ana işten sorumlu ve sürekli istihdam sağlarken, gerektiği durumlarda işgücüne başvurabilecekleri yeterli becerilerle donanmış geçici yardımcıları esnek çalışma modeliyle istihdam etme yolunu da seçebilmektedir (Neumark ve Reed, 2002, s. 4). Bu yeni çalışma stiliyle de örgütler, eskisinden farklı olarak daha dinamik, beceriler konusunda da esnek, takım ruhunu benimsemiş ve daha katılımcı aynı zamanda müşteri yönelimli bir hal almıştır (Stephen ve Coulter, 2001, s. 5). 


\section{Tele Çalışmanın Avantajları ve Dezavantajları}

Tele çalışma konusunda en çok olumlama, sosyal sorumluluk bakış açısıyla da değerlendirildiğinde çevreye yapmış olduğu etki sebebiyle yapılmaktadır. Özellikle sosyolojik boyutu ele alındığında toplumsal olaylara da bu çalışma stilinde daha fazla zaman ayırılabilir olduğu söylenmektedir. Evden çalışma olarak da değerlendirilebilecek bu durum, daha az trafik yükü, hava kirliliğine olumlu katkı, yakıt tasarrufu gibi durumlarla birlikte anılmaktadır. Bu çalışma stilini 'yeşil bir etkinlik' olarak nitelendiren görüşler de mevcuttur (Naktiyok ve İşçan, 2003, s. 56).

Tele çalışmanın avantajları ya da dezavantajları söz konusu olduğunda çok yönlü bir bakış açısı gerekmektedir. Tele çalışmada odakta çalışan varmış gibi görünse de firmalar da bu çalışma stilinin olumlu ya da olumsuz yönlerini deneyimlemektedir.

Durum; firma açısından incelendiğinde göze çarpan avantajlar; firmanın ofis alanlarından tasarrufundan başlamaktadır. Üretim tek bir zaman ve mekâna bağlı olmadığ 1 için artış gösterebilmektedir. İş devamsızlığı durumu kısmen ya da tamamen ortadan kalkabilmektedir. İlişskiler de daha esnek bir hal almaktadır ve bu bazı firmalar açısından avantaj olarak değerlendirilebilmektedir. Müşteri hizmetlerinin daha iyi sağlanabildiği ve böylece müşteri memnuniyetinin arttı̆̆ gözlemlenebilmektedir. İşletme yönetimi de amaçlara doğrudan yönelebilmektedir. Firma açısından dezavantajlar ise; öncelikle örgüt yapısının değişmesi olarak nitelendirilebilir. Ekipman maliyetlerinde bir artış görülebilmektedir. Görev seçiminde, yüz yüze çalışma biçiminden daha hatalı seçimler yapılabilmektedir. Çalışan motivasyonunun düşmesi durumunda, firma bu durumdan etkilenebilmektedir. Çalışanlar açısından avantajlar ise, esnekliğin verdiği özerklikten kaynaklı olarak kişisel özgürlüğü daha fazla hissetmek ve serbest çalışma şeklinden dolayı daha rahat çalışmak olarak nitelendirilebilmektedir. Çalışanların maliyetten tasarrufu da söz konusu olabileceği gibi aynı zamanda daha az iş problemi ile ilgilenme avantajını da yakalamış olmaktalardır. Ayrıca bu çalışma biçimiyle engelliler için de daha geniş çalışma alanı yaratılmaktadır. Çalı̧̧anlar için dezavantajlar ise; örgütsel olarak yaşanılması muhtemel zorluklar olarak karşımıza çıkabilmektedir. Takım çalışmasının yüz yüze çalışma biçimine göre daha zor olduğu söylenebilmektedir. Aynı zamanda statü kaybı kaygısı yaşayan çalışanların olduğu bilinmektedir. Terfiler zorlaşabilmekte ve tüm bunlar bazı psikolojik problemleri beraberinde getirebilmektedir (Perez v.d., 2002, s. 776).

Genel olarak olumlu ve olumsuz boyutlar yukarıda anlatıldığg gibi düşünülse de durum daha ayrıntılı incelendiğinde farklı durumlar da ortaya çıkabilmektedir. Bu durumların tamamı; çalışmanın uygulama bölümünde yer alan tematik alanlarda ve aynı zamanda değerlendirmeden sonra oluşturulan sonuç bölümünde detaylı olarak sunulmuştur.

\section{Araștırma Yöntemi}

Tele çalışma biçimi, Türkiye'de günümüzde sıkça görülen bir yöntem değildir. Türkiye'de etkileri 2020 yılında görülmeye başlayan Covid-19 salgınından sonra bazı işkolları 'uzaktan çalışma' adı altında tele çalışma yöntemiyle işleri sürdürüyor olsa da araştırmaya konu edilen çalışma biçimi yarı zamanlı ya da süreli olarak gerçekleştirilen tele çalışma yöntemi değildir. Hem araştırmanın nedenselliğini daha iyi anlayabilmek hem de konunun tekil örnekler üzerinden derinlemesine incelenmesi amaçlandığı için çalışma, nitel araştırma türünde tasarlanmıştır. Görüşülecek olan çalışanların belirlenmesi için ise nitel araştırma örnekleme yöntemlerinden amaçlı örnekleme olarak da kullanılan kartopu örnekleme yöntemi kullanılmıştır. Bu yöntemde temel amaç, araştırmanın üzerine kurgulanmış olduğu problemlere ilişkin verilere ulaşabilmek için konu hakkında en fazla bilgi sahibi olduğu düşünülen kişilerin saptanması ve görüşülen kişilerin önerileri doğrultusunda zincirleme şeklinde diğer kişilere ulaşılarak sahip olunan bilgileri zenginleştirmektir (Yıldırım ve Şimşek, 2008, s. 111). Tele çalışma biçiminin uzun süreli etkilerinin araştırılması hedeflenen bu çalışmada pandemi sebebiyle kısmi olarak tele çalışma yöntemine geçmiş olan kişiler değerlendirme kapsamına alınmamıştır.

\section{Veri Toplama Araçları}

Tele çalışma üzerine yapılmış bu çalışmada tele çalışma biçimiyle iş hayatında yer alan çalışanlarla görüşülmüştür. Görüşülenlerle, görüşmelerin tek bir şirketle sınırlı kalmaması için 
derinlemesine mülakat yöntemiyle görüşmeler gerçekleştirilmiştir. Kartopu örnekleme yöntemi kullanılarak 3 Kadın, 6 Erkek çalışanla görüşülmüştür.

Kartopu örnekleme yönteminde öncelikli olarak evrene ait birimlerden biriyle temasa geçilir. Temasa geçilen birim ya da kişinin yönlendirmesiyle ikinci birim ya da kişiye, ikinci birim ya da kişinin yönlendirmesiyle üçüncü birim ya da kişiye gidilir. Bu sırayı takip ederek sanki bir kartopunun büyümesi gibi örneklem büyüklüğü genişler (Yazıcıoğlu ve Erdoğan, 2004, s. 45). Çalışma konusunun Türkiye'de henüz görülme sıklığının yaygın olmamasından kaynaklı olarak amaçlı örnekleme yöntemlerinden olan kartopu örnekleme yöntemi kullanılmıştır. İlk olarak İstanbul'da bir firmada çalışırken özel durumları sebebiyle şehir değiştirmesine rağmen firmanın isteği üzerine tele çalışmaya geçen bir çalışanla görüşülmüş̧ür. İlk görüşmecinin yönlendirmesiyle farklı illerden ve farklı şirketlerden 8 kişi ile daha görüşülmüştür.

Görüşmeler; 2020 yılının Mart ayında başlayarak Mayıs ayında sona erdirilmiştir. Görüşülenlerle en az yarım saatlik görüşmeler yapılmış ve görüşmeler görüşülenlerin de izniyle kayda alınmıştır. Görüşülenlerin en az 2 yıldan bu yana tele çalışma biçiminde çalışıyor olmasına dikkat edilmiştir. Buradaki amaç; Türkiye'de etkileri 2020 yılında görülmeye başlayan pandemiden sonra bu çalı̧̧ma düzenine geçen çalışanların, kısa dönemde bu çalışma biçiminin etkilerini günlük yaşamlarında henüz tam anlamıla hissetmemiş olmalarından kaynaklanmaktadır.

Görüşmelerde yarı yapılandırılmış ve literatür taramasından sonra oluşturulmuş görüşme soruları kullanılmıştır. Cevaplar kendini tekrar etmeye başladığında ve belirli konular etrafında toplandığı belirlendiğinde görüşmeler sonlandırılmıştır.

\section{Verilerin Analizi}

Çalışmada, yapılan görüşmelerde elde edilen veriler, içerik analizi yöntemiyle incelenmiş ve literatür taraması sırasında oluşturan tematik olarak da değerlendirilebilecek başlıklar altında sıralanmıştır. Görüşmeler her bir görüşmenin kendi dinamiklerinin farkında olunarak çözümlenirken aynı zamanda diğer görüşmelerden elde edilen verilerle de benzerlik gösterdiği ya da farklılaştığı noktalarda nedensellik bağlamında da sorgulanmıştır.

Bunun sağlanabilmesi için de öncelikle tüm veriler incelenmiştir. Görüşmeler sırasında elde edilen benzer düşünce ve ifadeler bir araya getirilmiştir. Daha sonra elde edilen veriler düzenlenerek açıklama ve yorumlanmaları gerçekleştirilmiştir.

Literatürden elde edilen veriler, uygulama sırasında geliştirilirken; verilerin dikkat çekici şekilde toplandığı birtakım alanlar gözlemlenmiştir. Bu alanları, literatür taramasını da daha anlaşılır hale getirmek için çeşitli temalara ayırmak ihtiyacı doğmuştur. Yani ilk olarak literatür taraması sırasında oluşturulan tematik alanlar, uygulamadan sonra görüşmelerden elde edilen verilere bağlı olarak da geliştirilmeye devam edilmiştir. Tematik alanların son şekli; uygulama sonrasında tekrar literatürün gözden geçirilmesiyle ortaya çıkmıştır.

\section{Bulguların Yorumlanması}

Görüşmeler sonucunda elde edilen veriler doğrultusunda ve daha önce bahsi geçtiği gibi uygulama sırasında geliştirilen literatür taraması sonucunda konuyla ilgili çeşitli temalara ayrılarak yorumlanmıştır. Literatürde de tele çalışma hakkında çok farklı boyutlarda değerlendirilmelerin yapıldı ğı, çalışmanın teorik kısmında mevcuttur.

Çalışanlarla görüşmeler sonunda birçok çalışanın zamandan ya da harcamalardan tasarruf ettiği ya da iş ile ilgili bazı şeylere ayırdıkları zamanın ya da harcamaların arttı̆̆ını belirtmesi üzerine "maliyetler" adı altında bir tema oluşturulması uygun görülmüştür. Artan ya da azalan maliyetleri bir arada görmenin konuya daha bütünlükçü bir bakış açısıyla bakabilmeyi kolaylaştıracağı öngörülmektedir.

Çalışanların bazı konulardan bahsederken bahsi geçen konuları, iş verimliliklerine etki çerçevesinde değerlendirdiği dikkat çekmiştir. Bu sebeple verimliliği artırıcı ya da azaltıcı birtakım durumların yaşanıldığı gerekçesiyle "Verimlilik" teması altında bahsi geçen durumlara yer verilmiştir.

Benzer şekilde görüşülenlerin çalışma şekillerinden kaynaklı olarak özel yaşamlarına etkisine değindikleri ve bu durumun etik problemlerle bir arada yaşanıldığı dikkat çekmiş olup "Etik Sorunlar ve Özel Yaşam” teması oluşturulmuştur. Temada, çalışanların özel yaşama etkiden bahsederken olumlu 
yansımalarına değiniyor olsa bile bu durumun suiistimale açık olduğunu belirtmesi üzerine temanın ismi verilirken etik sorunların ve özel yaşamın ayrı ayrı incelenmesinin önüne geçmek adına bu tercihin yapıldığının belirtilmesinde fayda vardır.

"Fırsat Eşitliğì" teması; çatışmacı yaklaşımla ele alınıp bir değerlendirme yapılmasından ziyade, çalışanların tele çalışma yöntemi ile sahip olabilecekken; şirketin diğer çalışanlarından farklı olarak sahip olamadıkları firsatları incelemek üzere oluşturulmuştur. Fırsat eşitliği konusunda çalışanların, bu yöntemle çalıştıkları için memnuniyetini bildirdikleri herhangi bir durum olmamıştır.

"Sosyal Yaşam" teması ise, çalışmanın en çok öne çıkan durumlarından birisi olarak insan ilişkilerine yapılan vurgu sonrası son şeklini almıştır. Sosyal yaşamının kötü etkilenmesinden dolayı verimliliğin düştüğünü, bu durumun özel yaşamını da etkilediğini ve firsat eşitliğini yakalayamadıklarını belirten görüşülenler de olmuştur. Tele çalışma yönteminde ele alınan bu konunun, diğer konularla karşı1ıklı olarak en fazla etkisinin olduğu konu olduğu görülmektedir.

Görüşülenlerin hepsi 4 yıllık bir fakülteden mezun olup görüşülenler arasında lisansüstü eğitim almış olanlar da mevcuttur. Görüşülenlerin tamamı, çalışmanın da temeli oluşturan kavram olan tele çalışma biçiminde çalışmakta ve katma değerlerini bilgisayar ile sağlamaktadır. Görüşülenlerin yalnızca bir tanesi kendi işini kurmuş ve evden devam ettiriyor iken; diğer görüşmecilerin hepsi maaş karş1lığında çalı̧̧maktadır.

\section{Maliyetler: "Faturalarımı Artıyor"}

Bu çalışma stilinde, çalışanlar kendi mekânlarını kullandıklarından dolayı, işverenler için büyük işyerlerine sahip olmanın önemi azalmıştır. Daha küçük ofislerde, daha az kira, 1sınma gibi giderlerle maliyetler azaltılabilmektedir. Maliyetlerin azalması sadece bunlarla sınırlı kalmayıp mobilya, elektronik ve ofislerle ilgili araç gereçlerin satın alımı da azalmaktadır. Çalışan açısından da azalan masraflar söz konusudur. Örneğin çalışanlar yol masrafı yapmamakta ve kıyafet masraflarında normal çalışma düzenindekine göre bir azalma görülmektedir (Harrison, 1998, s. 5).

Konunun maliyetleri sadece ekonomik ölçülerle değerlendirilmemelidir. Zaman maliyeti açısından da hem işverene hem de çalışana çeşitli kazanımlar sağlanmaktadır. Yapılan bir araştırmada, çalışanın her gün sadece işe gelip gitme süresi hesaplandığında günlük 50 dakika gibi bir zaman dikkate alındığında yılda 5 haftalık bir süreyi kazanca dönüştürüldüğü görülmüştür (Apgar, 2001, s. 173). Durum Türkiye'de değerlendirmeye alındığında özellikle İstanbul gibi metropol şehirlerde bu kazanım yılda 5 haftadan çok daha fazla olabilmektedir.

Ancak maliyet konusunda sadece olumlu bulgulara yer vermek, çalışmanın eksik kalmasına sebep olacaktır. Özellikle çalışanlar açısından öngörülemeyen bazı durumlar söz konusu olabilmektedir. Çalışma mekânlarını işe uygun düzenlemek bu çalışma biçiminde çalışana düşmektedir. Çalışma mekânı olarak genellikle ev ortamı kullanıldığı için, verimliliğin artış gösterebilmesi ve ihtiyacın karşılanabilmesi için yeni bir düzenleme yapılması gerekmektedir. Bu düzenlemenin işverenler tarafından yapıldığı örneklerine rastlansa da işverenlerin de bu konularda çeşitli çekinceleri bulunmaktadır. Ev ortamının yeniden düzenlenmesi demek; 1sıtma, yalıtım ve aydınlatma gibi fiziki mekân düzenlemelerinin yapılması ve internet bağlantısının sağlanıp bilgisayarların ya da faks makineleri cihazların çalışanın kullanımına sunulması anlamına gelmektedir. Özellikle işin belirsiz olduğu durumlarda böyle düzenlemeleri gerçekleştirmek işveren için oldukça maliyetli olabilmekte ve bunu birden fazla çalışana sağlamaları durumunda ciddi bir yük oluşabilmektedir. Riskli olması nedeniyle çoğu zamanda böyle bir dönüşümün sağlanması işverenler tarafindan tercih edilmemektedir (Harrison, 1998, s. 5). Ancak uzun süreli istihdamlarda en azından çalışanlara bilgisayar ve gerekli teknolojik aletlerin sağlandığı bilinmektedir.

Görüşülen bütün görüşmeciler, almış oldukları ücretlerin, yapılan iş karşısında tatmin edici olduğunu vurgulamıştır.

Maliyet perspektifinden bakıldığında çalışanların almış oldukları ücretlerin yanında sosyal güvenlik kurumuna bağlı olarak çalıştıkları ve sigortalarının işyerleri tarafından karşılandığı da görülmektedir. Ayrıca evde kurmuş oldukları düzen için şirketlerinin kendilerine kullanım rahatlığına ve çalışanların isteklerine göre masa üstü ya da diz üstü bilgisayar temin ettikleri, gerekli olan hallerde de yazıc1, tarayıc1 gibi elektronik ofis malzemeleri ve hatta ek olarak kırtasiye malzemeleri dahi temin ettikleri dile getirilmiştir. Anlaşmaları gereği bazı çalışanlara yine çalıştı̆̆ kuruluş tarafından özel sağlık sigortası gibi imkânların verildiği de görülmektedir. 
Görüşülenler, evde çalıştıkları için artan ve azalan maliyetlerinin olduğunu dile getirmiştir.

(Erkek, 27, Yazilımc1);

"Evde olduğumuz için giderimiz yok değil, aksine bazı konularda giderlerimiz arttı. Örneğin ben evde yokken doğalgaz açık olmuyordu bu şekilde çalışmıyorken. Şimdi evdeyim sürekli ve neredeyse hiç kapanmıyor. Ama bunu şirketin karşılaması gibi bir durum söz konusu değil.”

Ayrıca elektrik faturasındaki artış ve evde internet bağlantısı olması için ödedikleri ücretleri de dile getiren çalışanlar mevcuttur.

(Erkek, 35, Destek Eleman1);

"Evde olduğumuzda ofis ortamındaki gibi yemekler hazır olmuyor. Çay almak istiyorsam, çalışma aralarında bir şeyler atıştırmak istiyorsam kendim yapmalıyım. Çalışırken ofiste hem sürekli sıcak ve soğuk içecekler hem de ikramlıklar olurdu. Öğle yemeği hazır olurdu. Bunların hepsi şu anda bizim için ekstra harcama."

Bununla birlikte azalan maliyetler de söz konusudur.

(Kadın, 38, Medya Tasarım ve Tanıtım);

"Kendimi biliyorum, eğer düzenli olarak bir ofis ortamında olsaydım giyimime kuşamıma çok fazla harcama yapardım. Ama şu anda böyle bir kaygım yok."

(Erkek, 33, Yazılım),

"Geçenlerde kendime kıyafet alışverişi yaptım çalışırken (!) giymek için, eşofman aldım birkaç tane."

Maliyetler konusu görüşmelerden de edinilen verilerden yola çıkılarak değerlendirildiğinde çok yönlü bir durum olarak karşımıza çıkmaktadır. Maliyetler; çalışanlar açısından incelendiğinde, literatürde bahsi geçen durumlarla örtüştüğü görülmektedir. Tele çalışma yöntemiyle çalışanların azalan birtakım maliyetlerinin olabildiği gibi, artan maliyetleri de söz konusudur. İşin sosyal maliyeti ayrıca dikkate alınması gereken bir konu olmakla birlikte ekonomik maliyetler -özellikle kış aylarında artan yakıt giderleri- dikkate alınmak suretiyle yeniden düzenlenebilir durumdadır.

\section{Verimlilik: "Yol Çekmiyorsunuz, Çalışın O Zaman"}

$\mathrm{Bu}$ çalışma biçimiyle verimliliğin arttığını savunan görüşler literatürde mevcuttur. Yapılan araştırmalara göre evden çalışanların, normal çalışma biçiminde çalı̧̧anlara göre ayda ortalama 4 saatten daha fazla çalıştıkları da tespit edilmiştir. İşletmeler bu durumdan kişi başına 1500 dolar civarında tasarruf yapabilmektedir (Butler ve Aasheim, 2007, s. 102). Ayrıca bu durum esnek çalışma saatleri kapsamında da düzenlendiği için çalışanlar en fazla verim aldıkları saatleri çalışmaya ayırarak da bir verim artışı gerçekleştirebilmektedir.

$\mathrm{Bu}$ çalışma biçimiyle çalışanların; işlerin stresinden, ofis ortamından daha az etkilendikleri gözlemlenmektedir. Çalışanların yıldırmaya (mobbing) uğrama ihtimali düşmektedir. Ofis ortamlarının iş sağlığ ve güvenliği uygulamaları dikkate alınmadan düzenlendiği durumda, evde daha güvenli bir ortamda çalıştığı söylenebilmektedir. İş teslimlerinin daha esnek olması dolayısıyla işyerinde işi bitirme zorunluluğu dolayısıyla işi aceleye getirme ya da özensiz sonlandırma gibi durumlar ortadan kalkmaktadır. Özellikle cinsiyete ya da fiziki farklılıklara göre görülebilen etik dışı ayrımcılık azalabilmekte ve hem kadınların hem de engellilerin normal şartlar altında çalışması görece zor olabiliyorken bu uygulamayla kolaylaşmaktadır. Tüm bu sebepler de verimliliği artıran unsurlar olarak karşımıza çıkmaktadır (Primo, 2003, s. 75).

Verimlilik söz konusu olduğunda bu çalışma biçiminin de sadece olumlu yönlerinden bahsetmek, konuyu bu bakımdan da eksik bırakabilecektir. Bilişim teknolojilerinin daha baskın olduğu iş yerlerinde bir denetim ve gözetim sorunu ortaya çıkabilmektedir. İşverenler kimi zaman çalışanlar üzerindeki kontrollerini yitirdikleriyle ilgili çeşitli kaygı ve endişelere kapılabilmektedir. Bu kaygıyı bertaraf 
edebilmek adına çalışanlardan farklı uygulamalar isteyebilmektedir. Örneğin, ofisin düzenli olarak aranılması, internet üzerinden denetlemeye imkân verecek düzenlemeler yapılması ya da e-postaların takibi bu denetleme biçimlerindendir (Sennett, 2011, s. 61). Özellikle yazılım sektöründe bilgisayarın aktif kullanım saatlerini raporlayan programların kullanılması da gündeme gelmekte ve kimi zamanlarda uygulamaya konulabilmektedir.

Çalışanların verimliliği kısmında bu çalışmada benzer ifadeler ortaya çıkmıştır ancak görülmektedir ki ofis düzeninden tele çalışmaya geçen görüşmeciler, evde çalışmak konusunda kendi iç motivasyonunu sağlamış durumdadır.

(Kadın, 38, Yazılımcı);

"Evde çalışmak iç disiplin gerektiren bir durum. Bu düzene geçer geçmez hemen kendime bir çalışma odası ayarladım. Çalışma psikolojisine girmek de önemli çünkü. Masada çalışmazsam önce koltukta ayaklarımı uzatıyorum sonra yayılmaya başlıyorum, bir bakıyorum uzanmışım. Ama masada ve odada tek başıma çalışırken iş havasına girebiliyorum."

(Kadın, 36, Yazılımc1);

"Ev dinlenme yeridir aslında. İş için ayrı bir düzen kurulmazsa verimli olmuyor çalışma."

(Erkek, 37, Yaz1lımc1);

“Mesai usulü çalışıyor olsak da erken kalktığım günlerde 7.00' de iş başı yapıyorum mesela. $\mathrm{O}$ zamanlarda daha verimli çalıştığımı da görebiliyorum zaman zaman. İşe gitmekle ilgili yoğunlukları ve yorgunlukları da çıkarınca, daha verimli çalıştı̆̆ımı söyleyebilirim."

(Kadın, 38, Yazılımcı);

"Yardımlaşmanın azaldığını söyleyebilirim. Özellikle ekip çalışmasında, verimi azalttığını görüyorum. Ofiste olsam masasına gidip 2 dakikada sorunu anlatıp cevap alabileceğim bir çalışma arkadaşıma bu şekilde olunca telefonla, bilgisayarla ulaşmak için çaba harcıyorum, müsait değilse, sorun bekledikçe bekliyor. Bu da aslında bakınca verimi düşürüyor.”

(Erkek, 27, Yaz1lımc1);

"7/24 destek vermekle yükümlüyüm. Ofiste çalışırken kimin ne yaptığı belli aslında. Ev düzeninde kendini kanıtlama ihtiyacı doğuyor. 'evde yatıyorum zannetmeyin' mesajını vermek için verimi artırıyorum kendimce. Ayrıca yönetici de evde olduğumu bildiği için daha fazla yüklenebiliyor. İş arkadaşlarımdan bazen açık açık 'Yol çekmiyorsunuz, çalışın o zaman' imasını alabiliyorum rahatlıkla. Ekip çalışması konusunda da şirkette toplantı odası müsait olmadığında bir araya gelinmezken, şu anda müsaitlik durumu diye bir şey söz konusu değil, hemen online görüşme yapıllyor, işler yürüyor."

(Kadın, 36, Yazılımci);

"Ofisteyken yeni biri işe alındığında yapmasını istediğimiz işlerde onu bir eğitime tabii tutuyorduk. Her gelen için bu tekrarlanıyordu. Benim verdiğim eğitimlerde ben yeni gelenlere konumlarına göre verdiğim eğitimleri kaydediyorum. Benzer pozisyona alınacak yeni çalışanlar, zaten verilmiş ve kaydedilmiş olan eğitimleri izliyorlar. Tekrar anlatmak zorunda kalmiyorum."

Verimlilik konusu, çalışanın bireysel durumları da dikkate alındığında çalışanlara göre değişebilen bir durum olarak karşımıza çıkmaktadır. Bazı çalışanlar tek başlarına işlerini evde ancak ofis ortamı gibi bir alanda gerçekleştiriyorken değerlendirmesi farklı olabilmekte iken; ailesi ve özellikle çocuklarıyla yaşayan kişilerin bu konudaki değerlendirmeleri farklılaşabilmektedir. Ancak unutmamak gerekir ki bu çalışma biçimini kabullenmiş olan çalışanlar, verimliliklerini artırmak konusunda da kendi içlerinde bir motivasyona sahiptir.

Bireysel değerlendirmeler çalışanların sahip oldukları imkânlara göre değişmektedir. Örneğin esnek çalışma saatlerini, verimli olduğunu düşündüğü sabah saatlerinde çalışabilme imkânı çerçevesinde değerlendirip kazanım olarak değerlendiren çalışanlarla birlikte, aynı olguyu her an iş 
başına geçmesi istenmesi ihtimalini düşünerek sürekli tetikte olma halini betimleyen ve bu durumun olumsuzluğunu vurgulayan çalışanlara da rastlanılmıştır. Hatta bu durumun sürekli iş düşündürmesine sebep olarak uzun vadede tükenmişlik hissine kapılma durumuna yol açması da ifadelerden çıkarılabilecek yargılardan biridir. Yine benzer şekilde, ekip çalışmasının yeni öğrenme firsatlarını beraberinde getirdiğini düşünüp bundan yoksun kaldığ 1 için olumsuz bir yansıma olarak gören çalışanlar mevcutken; ekip çalışmasının beraberinde bir çatışma alanı yaratabileceğini düşünerek ekip çalışmasından kısmen uzak kalmasının verimliliğe olumlu katkı yaptığını belirten çalışanlar da mevcuttur.

\section{Etik Sorunlar ve Özel Yaşam: "Başında Patron mu Var?”}

Etik ve özel yaşamla ilgili konular genellikle olumsuzluklar etrafında toplanmıştır. Evden çalışma özellikle yalnız yaşamayıp ailesiyle aynı evi paylaşan çalışanların hayatlarında bir takım sıkıntılara yol açabilmektedir. Örneğin, özellikle ekiple birlikte bir sanal çalışma grubunun içinde olan bireylerin, diğer ekip üyelerine ayak uydurması gerekeceğinden aile fertleriyle çeşitli uyumsuzluklar yaşaması muhtemeldir (Kurland ve Bailey, 1999, s. 60). Yine aynı sebepten, bireylerin kendileri için sosyalleşmeye ayırdıkları zamanlarda, işin taleplerine bağlı olarak bir sınırlama ya da kısıtlama hissetmeleri olasıdır (Haddon, 1998, s. 5). Yapılan planlar ertelenebilmekte ya da iptal edilebilmektedir.

Evden çalışmanın olumlu özellikleri baskın gelip bu çalışma biçimine geçen çalışanlarda, evden yürütülen işin sürdürülebilmesiyle ilgili bir kaygı durumu oluşabildiği de gözlemlenmektedir. Kontrol kaybıyla ilgili kaygılar ortaya çıkabilmekte ve özellikle iş hayatının getirdiği sosyalleşmeden uzak kaldıkları için bir izolasyon yaşamaları da söz konusu olabilmektedir (Fu vd., 2012, ss. 416-423). Özel yaşamı en fazla etkileyen durumlardan biri sosyalleşmedir. Bir süre sonra iş arkadaşlarına yabancılaşma durumu da görülebilmektedir.

Özellikle bilgi teknolojileri söz konusu olduğunda günümüzde de mahremiyetle ilgili kaygılar yaşayabilmekteyiz. İşyerlerinde bilgisayarlar merkezi kontrol altındadır ve güvenlik sistemleriyle birlikte mahremiyetle ilgili kaygılar en aza indirilebilmektedir ancak bu durum ev ortamındaki bilgisayarlar ve çalışanlar için pek mümkün olamamaktadır (Tanılır, 2002, s. 39). Hem çalışanın oluşturmuş bilgilere erişim konusunda, çalışanın iş ile ilgili gizli bilgileri paylaşması konusunda ya da ev ortamında bulunan farklı kişilerin işle ilgili bilgilere ulaşması konusunda etik sorunlar gündeme gelebilmektedir.

Yine benzer şekilde evden çalışan bir çalışanın işvereni tarafından; çalışanın özel alanına müdahale durumu ve bunun meşrulaşması sorunu gündeme gelebilmektedir. Çalışanın veriminin düştüğü tespit edildiği noktalarda ilk düşünülen durum; ev ve özel hayatla ilgili yaşanılan sorunlar olabilmekte ve işverenler bu konuda uyarı yapabilecekleri konusunda bir hisse kapılarak müdahil olma ihtimali yükselmektedir. Ayrıca örneğin ev telefonunun iş telefonu olarak kullanılması durumunda da farklı durumlar ortaya çıkabilmektedir. İş sebebiyle yapılan görüşmelerin tespiti ve işveren tarafından finanse edilebilmesi için telefon dökümlerinin tamamının alınması ve işverene teslim edilmesi durumunda da bir mahremiyet konusu gündeme gelebilmektedir (Guthrie 1997, s. 30). Bu tespitteki ilk durum devamlılığını sağlıyor olsa da artık şirketlerin iş telefonu olarak mobil hat ve hatta telefon sağlaması durumunda bu problem ortadan kalkabilmektedir.

Ortaya çıkan etik problemlerin en dikkat çekici olanlarından biri; bilgisayarlarda kullanılan ve iş için gerekli olan yazılımların ofis şartlarında lisanslı kullanılıyor olmasına rağmen, ev ortamında lisanssız ya da kopya yazılımların kullanılması olarak değerlendirilebilmektedir. Bu gibi korsam olarak da adlandırılan yazılımların kullanılması etik bir problem olarak karşımıza çıkmaktadır (Guthrie ve Pick, 1997, s. 3).

Tele çalışma konusunda etik sorunlar birçok teknolojik destekle aşılabiliyor olsa da özellikle görüşmelerin görüntülü yapıldığı zamanlarda özel yaşamla ilgili kaygılar yaşayan çalışanların olduğu gözlemlenmiştir. Bu kısımda özel yaşam bahsi geçen etik değerler üzerinden değerlendirilecek olup tele çalışmanın sosyal hayata etkisi bir başka başlık altında ve daha derinlemesine incelenecektir.

(Erkek, 33, Yazilımc1);

"Bu çalışma biçimi karşılıklı güven üzerine kurulu. Güven ilişkisi önemli. Çalıştığım şirket, yurtdışı menşeili ve saat farkı yüzünden her işte mesai usulü çalışmıyoruz. Amerika'daki müşterilerle iletişim kurmak için Türkiye'de mesai dışı saatlerde olmak 
gerekiyor. 'Nasıl olsa çalıştım' deyip normal işleri aksatmak mümkün ancak bunu yapmıyorum, şirketim de bu konuda beni bilir ve bana güvenir."

(Kadın, 36, Yazılımcı);

"Bu şekilde çalışmaya başladığımda apartmandan komşular çat kapı gelmeye başladı. Onlara çalışıyor olduğumu belirtsem de çok anlamıyorlardı bu ş̧ekilde çalışma yapılabileceğini. Aslında mesai yapıyorsunuz ve yaptı̆̆ınız iş karşılığında size ödeme yapılıyor ancak 'nasıl olsa evde' düşüncesini yıkabilmek zaman aldı. Bir de 'buluşalım işte ne olacak, başında patron mu var sanki?' gibi bir yaklaşım var. Önemli olan patronun başımda olması değil, ben bu işi yaparak para kazanıyorum, içim rahat olmalı."

(Erkek, 37, Yazilımc1);

"Evde 3 yaşında bir çocuğum var. Bir gün çalışma bittikten sonra bilgisayarı açık vaziyette bırakıp odadan çıkmıştım. Çocuğum bilgisayarda yanlışlıkla çalışma arkadaşımı görüntülü aramış, görünce hemen müdahale ettim, o günden sonra da daha dikkatli davrandım."

(Erkek, 35, Destek Eleman1);

"Görüşmelerin görüntülü yapılıyor olması aslında birtakım sıkıntıları beraberinde getirebilir. Bazen ekran paylaşırken aynı zamanda uzun süre sesli görüşme de açık kalmak zorunda olabiliyor. Özellikle yalnız yaşamıyorsanız, evin içindeki bütün seslerin; yüzlerini belki hiç görmeyeceğiniz insanlar tarafından duyması rahatsız edici olabiliyor. Kendim için duvarı arka plan yapabildiğim bir alan oluşturdum ancak ev kalabalık olursa yatak odasında da çalışmak zorunda kalabiliyorum. Bu durum bazen can sıkabiliyor."

(Erkek, 27, Yazılımc1);

"Benim yanımda kardeşim var, bu tür olayları yaşamıyorum ama geçen gün küçük çocuğu olan birisi sesli görüşme yaparken çocuğu ona bağırdığı için çocuğuna geri bağırıyordu, biz de hepsini duyuyorduk."

Yukarıdaki ifadelerden de anlaşılabileceği gibi, işlerin gerçekleştirilmesiyle ilgili etik sorunların yanında özel yaşamla ilgili etik sorunlar da görülebilmektedir. Çalışanların sürekli izlenmiyor olması, yönetimin denetimine çok açık olmayan durumların da iş sırasında ortaya çıkması, işin suiistimal edilmesi konusunda çalışanların etik anlayışına kalabilmektedir ve bu durum çalışanlar tarafından ifade edilmektedir. Özel yaşamda da benzer durumları yaşayanların, içinde oldukları durumu değerlendirme biçimlerinde bir farklılaşmaya sebep olduğu görülmektedir. Ev ve iş sorumluluklarının eş zamanlı idaresini olumlu gören çalışanlar mevcutken; bu alanların ayrı alanlar olmamasından kaynaklı olarak bir çatışma durumu yarattığını ifade eden çalışanlara da rastlanılmaktadır. Bununla birlikte, bazı çalışanlar, durumu; mahrem olarak değerlendirilebilen bir ortamı özellikle görüntülü aramalarla tanımadıkları kişilere sunmak olarak yorumlayabilmektedir. Bu konuda da alternatif bir çözüm yolu geliştirmesi konusunda istekli oldukları da gözlemlenmiştir.

\section{Fırsat Eşitliği: “Evde Çalışmak mı, Ofiste Uyumak mı?”}

Fırsat eşitliği, pek çok bakımdan incelenebilecek ve hatta ortaya çıkan durumların pek çoğu, etik problem olarak da değerlendirilebilecek bir konudur. İşverenlerin çalışanların evden çalışmasına firsat verdiği durumlarda bazı hakları kendilerine sağlamamak gibi özünde etik dışı davranış olarak da değerlendirebilecek birtakım uygulamalarda bulunduğu görülebilmektedir. Çalışanların evden çalışması durumunda daha az ücret aldıkları gibi durumlara rastlanılmaktadır. Aksi örnekleri olmakla birlikte İngiltere'de durumun örneği sayılabilecek uygulamalara rastlanmıştır. Kısmi süreli çalışan kadınlar ve erkekler arasında da bir fark olmakla birlikte oran; kadınlarda, normal süreli çalışan kadınların ücretinin 4/5'i kadarken, erkeklerde normal süreli çalışan erkeklerin ücretleriyle $2 / 3$ oranıyla seyretmektedir (Yavuz, 1995, s. 26). Örnekteki şekliyle incelendiğinde, evde çalışanların hem cinsiyet ayrımına hem de çalışma biçimi ayrımına maruz kaldıkları görülmektedir.

Konuyla ilgili firsat eşitsizliğine sebep olan bir başka durum sendikal hareketlerde görülmektedir. İşyerine bağl11ık ve çalışanlar arasındaki dayanışmanın görece az olması dolayısıyla çalışanların 
sendikalaşma oranları daha düşük seyredebilmekte ve çalışanların işten çıkarılması kolaylaşmaktadır (Gökbayrak, 2005, s. 66). Ancak bu durum, ofis ortamında bulunmayan işçilerin daha az ayrımcılığa uğraması dolayısıyla sendikal haklarını kullanmak isteyecekleri durumlarla daha az karşılaşmasından da kaynaklanabilmektedir.

Yine iş ortamından uzak kalmakla ilgili firsat eşitsizliğinin yaşandığ 1 bir başka alan, kariyer planlaması olabilmektedir. Çalışanlar kariyer planlarından uzak kalabilmekte ve böylece gelecekleri de belirsizleşebilmektedir. Ancak ofis ortamlarında bu durum çok sık görülmemektedir (Birsel, 2007, s. 156).

İşverenlerin evden çalışan çalışanlarına yaklaşımı 'evde rahat çalışıyor, fazla işe de katlanabilir' düşüncesi çerçevesinde şekillenebilmektedir. Bu gibi durumlarda da aslında yine etik olmayarak evden çalışan kişilere daha fazla iş yükü yüklenmesi, çalışanların da çalışma saatlerinin dışında ya da hafta sonları çalışmak zorunda kalması gibi bir durumu doğurabilmektedir. Hatta bu durum özel hayatını da etkiler bir hale gelebilmektedir. Gerçekleştirilen fazla çalışmanın karşılığının alınamaması durumu da görülebilmekte ve bir firsat eşitsizliği de bu noktada ortaya çıkabilmektedir (Eyrenci ve Bakırcı, 2000, s. 19).

Fırsat eşitliği konusu, tele çalışma biçimde çalışanların belirttiğine göre sıkıntı yaratan bir durum değildir. Bu biçimde çalışanların hepsi sosyal güvenlik kurumuna dâhil olduklarını belirtmişlerdir. Cinsiyet konusunda da bu çalışma biçiminde bir ayrımcılıkla karşılaştı̆ıııı belirten olmamıştır. Ancak amaçlı örnekleme yöntemlerinden olan kartopu örnekleme yöntemi kullanılmış olsa da görüşme yapılan kadınların ve erkeklerin sayısındaki farklılık göze çarpmaktadır. Ancak bu çerçevede bir durum değerlendirmesi yapmak için de bu çalışmanın örneklem grubundaki sayı, nitel bir çalışma olduğu için, anlamlı bir korelasyon oluşturmamaktadır. Fırsat eşitliği konusunu görüşülenlerin neredeyse tamamı ofis ortamında olmak ya da olmamakla ilişkilendirmiş ve ofis ortamında olmamaktan dolayı avantajlı bir durumun içinde olduğunu belirten çalışanlara da rastlanmıştır.

(Kadın, 38, Yazılımc1);

"Sosyal haklar konusunda hiçbir sıkıntı yaşamıyorum. Zaten bu haklardan faydalanabilecek duruma gelmek için de bir etkileşimin içinde olmak gerekir. Ofis ortamında çeşitli entrikaların döndüğü bir gerçek. Ancak ben bu çekiş̧melerin dişında kalıyorum. Bana söylenen işi yapıyorum, bitiyor. Şirketim de herhangi bir ayrımcılık yapmadığı için mutluyum.”

(Erkek, 33, Yazilımc1);

"Fırsat eşitliğini şöyle değerlendiriyorum aslında; ofiste mesai saati bitince çıkıp gidebilen insanlardan daha çok çalışıyorum. 'Mesai bitti, haydi bilgisayarı kapatayım' kavramı yok bir defa. Bazı zamanlarda yoğunluğa bağlı olarak hayatımız iş oluyor. Aslında ofiste çalışsam kapatıp gidebilme şansına sahip olurum ama gece gündüz demiyoruz düzenimiz evde olunca."

(Erkek, 35, Destek Eleman1);

"Evde çalışıyor gibi değil de işyerinde uyuyor gibi hissettiğim çok oluyor. Başkaları 'bilgisayarım yanımda değil, sistem şirkette çalışıyor sadece' deyip çalışmama ya da işi erteleme şansına sahipken; siz evde çalışıyorsanız böyle bahaneleriniz olamıyor.”

(Kadın, 36, Yazılımc1);

"İşyerinde bulunmanın çeşitli imkânları bulunuyor. Örneğin işyeri hekimleri var faydalanılabilen. Biz aynı şehirde bile değilken, bu haktan da faydalanamıyoruz doğal olarak. Ayrıca işyerinde çeşitli eğitimler, toplantılar, etkinlikler düzenleniyor. Bunların büyük bir çoğunluğundan mahrum olarak çalışıyoruz."

Fırsat eşitliği konusu, çalışmada en az bahsi geçen konulardan biri olmuştur. Yeni kariyer ve iş imkânlarındaki kısıtlılık, terfilerin zorlaşması ve işyerinde sağlanan imkânlardan genellikle faydalanamadıklarında değiniyor olsalar da çalışanların hepsi sosyal güvenlik sistemine dâhil olmalarını fırsat eşitliği için yeterli olarak gördüklerini belirtmiştir. Konuyla ilgili yaşanan tek ciddi sıkıntı, mesai 
saatlerini aşabilen çalışma saatleridir. Ancak bu durumda da hemen hemen bütün çalışanlarda bir kabullenmişlik gözlemlenmiştir.

\section{Sosyal Yaşam: "Home-Hapis"}

Tele çalışma düzeninde maddi kazanç yolunu seçmiş çalışanlarda sosyal anlamda ciddi bir rahatsızlık gözlemlenmiştir. Görüşülenlerin hemen hepsi bu düzenin çalışanları asosyal olmaya zorladığını belirtmiştir. Bu durumun karaktere bağlı olarak avantajlı olduğunu düşünen sadece bir çalışana rastlanmıştır.

(Kadın, 38, Yazılımc1);

Biz Türk insanıyız. İş ilişkilerimizde bile bir sıcaklık arıyoruz aslında. Ofis ortamındaki gibi bir şeylere dâhil olmak istiyor insan. Bu çalışmada ama yöneticin sana sadece işi soruyor. Birlikte yemeğe gitmek bile önemli. Çalışırken bile olsa insanların gözünün içine bakabilmek verimi bile artırır. Ben şirketten ayrıldıktan sonra işe girmiş bir arkadaşla telefonda görüştük uzun zaman. Eğitim için şirkete gittiğimde, o arkadaşımla ilk karşılaşmamda sarıldık. Bu duygu başka."

(Erkek, 37, Yazilımc1);

"Ailem ve arkadaşlarım bu durumu serbest zaman gibi gördü uzun süre. 'Oh, ense' diyen de oldu, 'nasıl olsa evdesin' diyen de. Bu düzende çalışmayan için anlaması çok zor. Tam ben odaklanmış çalışıyorken bir şeyler isteyebiliyorlar. İşi kesmiş oluyorlar fakat farkında değiller. Benden istekleri olduğu zaman 'Ben evde olmasaydım ne olacaktı?' diye sorduğum çok olmuştur. Ofiste olsam çocuk hasta olsa örneğin, yarım gün izin alır gelirim ancak böyle olunca sürekli benim de çocukla ilgilenmem, hastaneye götürmem gerekebiliyor. Aile-iş-arkadaşlıklar hepsi birbirine giriyor. Özellikle aile ilişkilerinde gerginlikler yaşanabiliyor. Aile düzeni için ofise gidiyor olmak önemli aslında.”

(Erkek, 35, Destek Eleman1);

"Ne çalışırken işteyiz, ne dinleniyorken evdeyiz. Öyle bir arada kalmışlık. Evdekiler bilgisayar başında vakit geçiriyorum gibi görüyor, iştekiler 'nasıl olsa evdesin' diyor. Karmakarışık."

(Erkek, 31, Yazılımc1)

"Bu düzene ilk geçtiğimde yakın çevrem 'maaşını alabiliyor musun?' diye soruyordu. Toplumun gözünde öyle bir alg1 var. Açık olarak söyleyebilirim ki asosyaliz. Görüntülü görüşmeler hiçbir zaman yüz yüze görüşmenin yerine geçemez. Sosyal çevremiz kalmadı. Diğerleri de ofiste, birlikte, biliyorsunuz. Bazen zorlayıcı olabiliyor. Birkaç gün evde, birkaç gün ofiste çalışmayı isterdim."

(Kadın, 38, Medya Tasarım ve Tanitım)

"Çalıştığım kişilerle uyum problemi yaşayabiliyorum yüz yüze olmadığı zaman. Karşıdaki için kimliksizsiniz aslında. Yazışma dilinden de oluyor bu. Ben zaten uysal bir insanımdır. Yazışırken de sürekli kibar bir dil kullandığım için karşıdaki her şeyi yaptırabileceğini sanıyor. Yüz yüze gelince, ete kemiğe bürününce yaklaşımlar da değişebiliyor bazen. Ben üniversitede çok aktiftim. Haftada 2-3 gecem dışarıda geçerdi. Şimdi hafta içi neredeyse hiç çıkmıyorum. Arkadaşlarımla buluşabilmek için şimdi ciddi bir programlama yapmam gerekiyor. Yine de o saatte işim çıkabiliyor ya da işim buluşma saatine uzayabiliyor, o zaman da önden eşimi gönderiyorum, ben daha sonra onlara dâhil oluyorum.”

(Kadın, 36, Yazılımc1);

Arkadaşlarım onları ekmek için bahane olarak işimi kullandığımı düşünüyordu. Sizi zaten 'ev hanımından hallice' olarak görüyorlar. Örneğin bir gün gittiğim kuaförde ne iş yaptığımı sordular, evden çalıştığımı belirtince kuaför çalışanı 'olsun' dedi. Sosyalleşme konusu, ciddi bir sıkıntı." 
(Erkek, 27, Yazılımc1)

"Karşında sürekli dijital biri var gibi. Nerede, kimle, hangi firmada çalıştığını bile anlayamiyorsun bazen."

(Erkek, 33, Yazilımc1);

"Eğer evde çalışan insanlar, arkadaşları ya da ailelerinden anlayış konusunda şikâyet ediyorsa kendilerini sorgulamaları gerekir. Çok yakın bir komşum var, 2-3 gün görüşmesek küserler bana. Başlarda çöp atmaya falan çıktığımda birlikte vakit geçirmek için ısrar ediyorlardı. İşim yokken bile 'var' dedim, sınırımı çizdim, aşamadılar. Biraz da karakter meselesi. Ben yalnızlığı çok seviyor ve tercih ediyorum zaten özel hayatımda da. Tam istediğim şekil ve şartlarda çalışıyorum."

Çalışmanın en çarpıcı sonucu tele çalışmanın sosyal boyutu görüşülürken ortaya çıkmıştır. Görüşülenlerin hepsi 'asosyal' kelimesini kullanmıştır. Mevcut arkadaşlıklarında mesai saatlerinin esnekliği yüzünden görüşmelerin azalması konusuna etki olduğundan bahsetmişlerdir. Sosyalleşme ihtiyacını aileleriyle bir arada yaşayan çalışanlar, aileleriyle karşıladıklarını belirtmekteyken; sosyal hayatının kalmadığını belirten çalışanlara da rastlanılmıştır. Hem yoğun iş temposu hem de sosyal arkadaşlıkların bir arada yürümediğini söyleyen çalışanlar da mevcuttur. Hatta konuyla ilgili olarak arkadaşlıklardan ziyade; iş yaparken müşterileriyle, çalışma arkadaşlarıyla ve hatta patronlarıyla da bazen aylarca yüz yüze ilişki kuramamaları ortaya çıkan durumlardan biridir. Çalışanların bu konunun kendilerini gerçekleştirme konusunda negatif yansımasından bahsettikleri görülmektedir. Yeni yaygınlaşmaya başlayan bu çalışma şeklinde halkın olumsuz tepkileri de çalışmanın sosyal boyutlarının arasında değerlendirilebilecek sosyal durumlardan biri olarak karşımıza çıkmaktadır.

\section{Sonuç}

Tele çalışma kimi zaman şirketin sunduğu bir opsiyon, kimi zaman bir zorunluluk, kimi zaman da istek olarak değerlendirilmektedir. Tele çalışmanın çalışanlar tarafından nasıl değerlendirildiğini ve toplum tarafindan nasıl okunduğunu çalışan gözünden ele alan bu çalışmada dikkat çekici sonuçlara rastlanmıştır.

Her çalışanın sabit bir iş yerindeki gibi aynı imkân ve şartlara sahip olmadıkları bilinmektedir. Farkı yaşlarda, farklı cinsiyetlerde ve farklı yaşam biçimlerindeki bireylerin tele çalışma biçimiyle çalışma hayatında yer alabildikleri görülmektedir. Yalnız yaşayan ya da çocuğu olmayan bireylerin evden çalışmakla ilgili çok büyük sıkıntıları olmamakla birlikte, yalnız yaşamayan, özellikle küçük yaşta çocuğu olan ya da eşi çalışma saatlerinde evde bulunan kişilerin ev hayatlarının bu durumdan etkilendiğiyle ilgili bulgulara rastlanmıştır.

Artan ve azalan maliyetler değerlendirildiğinde, çalışanların her iki duruma da vurgu yaptıkları görülmektedir. Ancak özellikle tüketimin artması üzerinde durarak kendilerine ekstra haklar tanınması (fatura desteği gibi) gerektiği üzerinde durdukları görülmektedir.

Dikkat çeken önemli durumlardan biri; görüşülenlerin hemen hepsinin evde kendilerine ait bir çalışma alanı oluşturmanın iş motivasyonunu ve verimini artırdığını düşünmesidir. Uzun süre bu çalışma biçiminde iş hayatında bulunan kimselerin; çalışma biçimine geçici bir durum olarak bakmadığından dolayı, ev alanlarını çalışma biçimine uygun düzenledikleri sıkça ifade edilmiştir. Bu durum olumlu olarak işe yansıması görülen bir durum iken; aynı zamanda çalışanların özel alan düzenlemesini yeniden yapması gereken bir durum olarak da karşımıza çıkmaktadır. Evde sürekli olarak çalışmaya hazır bir düzenin olmas1; beraberinde bazen istenilen bazen istenilmeyen şekilde bir hazırbulunmuşluk durumunu getirmekte ve farklı çalışanlarca hem olumlu hem de olumsuz değerlendirilebilmektedir. Aynı zamanda çalışanların hepsi işlerin mesai usulünde yürüdügü durumlarda bile mesai saatleri dışında çalıştıklarını dile getirmiştir. Bazı görüşmeciler, iş yerinde çay saati gibi boşluklarının olduğunu belirtirken, tele çalışma sisteminde çalıştıkları durumlarda çalışırken yemek ihtiyacını aynı zamanda giderip çalışmalarını bölmediklerinden de bahsetmiştir.

Ev ortamının aynı zamanda iş ortamına dönüşmesinin zaman zaman beraberinde birtakım olumsuzlukları getirdiği görüşülenlerin yine sıkça üzerinde durduğu durumlardan biridir. Çalışırken vermiş olduğu arada ev işlerini de halledilmek olumlu olarak düşünülse de; bireylerin çalışırken 
dinlenme ihtiyaçlarının olduğunu ve bu ihtiyaçların ayrı bir mekânda karşılanması gerektiğine vurgu yapan çalışanlar da mevcuttur.

İsyerinde normal çalışma düzenindeki çalışanlardan bazı haklar ve firsatlar konusunda ayrıldıklarını dile getiren çalışanlara da rastlanılmıştır. Çalışanların en olumsuz etkilendikleri alan kuşkusuz sosyal yaşam alanında toplanmaktadır.

Çalışmanın sonunda tele çalışma biçiminin çalışan tarafından değerlendirildiğinde avantajları ve dezavantajları şu şekilde özetlenebilmektedir;

Tablo 1. Tele çalışmanın avantajları ve dezavantajları

\begin{tabular}{|c|c|c|}
\hline & Avantajlar & Dezavantajlar \\
\hline Maliyetler & $\begin{array}{l}\text { - Giyim ve kişisel bakım (tıraş, } \\
\text { makyaj vb) için ayrılan zaman ve } \\
\text { harcamalardan tasarruf, } \\
\text { - Trafikte zaman kaybetmemek, } \\
\text { - Yakıt tasarrufu, } \\
\text { - Çevre kirliliğinin azalması. }\end{array}$ & $\begin{array}{l}\text { - Enerji tüketimine ait giderlerin } \\
\text { artmas1, } \\
\text { - Gida tüketimine ait giderlerin } \\
\text { artmas1, } \\
\text { - Bilgisayar, yazıcı, internet gibi teknik } \\
\text { harcamalara ait giderlerin artması. }\end{array}$ \\
\hline Verimlilik & $\begin{array}{l}\text { - Esnek çalışma saatleri, } \\
\text { - Bireysel çalışmanın artması ve } \\
\text { özerklik hissi, } \\
\text { - Trafiğe bağlı streste ve yorgunlukta } \\
\text { azalma, } \\
\text { - İstenilen şehirden çalışma imkânı, } \\
\text { - Erken saatte uyanmamak, } \\
\text { - Şirket içi bireysel ilişkilerden } \\
\text { kaynaklı problemlerin daha az } \\
\text { görülmesi. }\end{array}$ & $\begin{array}{l}\text { - Daha çok çalışılmasının beklenmesi, } \\
\text { - Yardımlaşmanın azalması, } \\
\text { - Ekip çalı̧̧masının ve } \\
\text { motivasyonununun kısıtlanması, } \\
\text { - Dijital iliş̧kilerin yorucu olması, } \\
\text { - Tükenmişlik hissinin yaşanabilmesi. }\end{array}$ \\
\hline $\begin{array}{c}\text { Etik Sorunlar } \\
\text { ve Özel Yaşam }\end{array}$ & $\begin{array}{l}\text { - Ev işlerinin eş zamanlı idaresi, } \\
\text { - İş arkadaşlarını idare etme } \\
\text { zorunluluğunun olmaması, } \\
\text { - Çalışma planını özel yaşamına } \\
\text { uygun esnetebilme imkânı. }\end{array}$ & $\begin{array}{l}\text { - Ev ve iş sorumluluklarının iç içe } \\
\text { geçmesi, } \\
\text { - Dinlenme alanlarının aynı zamanda iş } \\
\text { alanı haline gelmesi, } \\
\text { - Dijital sesli ve görüntülü aramaların } \\
\text { gerçekleşmesi sonucu mahremiyetin } \\
\text { kimi zamanlarda ihlal edilebilmesi. }\end{array}$ \\
\hline Firsat Eşitliği & & $\begin{array}{l}\text { - Yeni iş ve kariyer imkânlarına } \\
\text { erişimin kısıtlı olması, } \\
\text { - Terfilerin zorlaşması, } \\
\text { - İşyerindeki eğitimlerden, } \\
\text { imkânlardan, toplantı ve } \\
\text { eğlencelerden faydalanamama. }\end{array}$ \\
\hline Sosyal Yaşam & - Daha esnek ilişkilerin kurulması. & $\begin{array}{l}\text { - Sosyal ilişkileri kötü etkilemesi, } \\
\text { - Yüz yüze iş etkileşimini aza } \\
\text { indirmesi, } \\
\text { - Yeni kişilerle tanışma imkânının } \\
\text { olmaması, } \\
\text { - Toplumsal baskı hissedilmesi. }\end{array}$ \\
\hline
\end{tabular}

Tüm bu değerlendirmelerden sonra, aslında tele çalışma biçimiyle evde çalışma düzeninde çalışan kişilerin, bir hapsolmuşluk durumundan bahsedilebilmektedir. İş ortamı ve işe gidip gelirken kurulan ilişkiler, sosyal birer varlık olan insanların sosyal ihtiyaçlarını karşılaması için de bir aracı durumundadır. Tele çalışma düzeninde çalışan kimseler, farklı şehirlerde ikamet eden kişilerle iş yapmakta ve bir süre sonra, sürekli evde olmasından dolayı yeni kişilerle tanışma firsatını bulamamakta 
ve sosyal ilişkilerinin devamlılı̆̆ını sağlayamamaktadır. Böylece eve, dolaylı olarak da işe hapsolmuş bireylerin ortaya çıtığı görülebilmektedir.

Bir başka önemli durum, çalışanların sürekli teknolojik aygıtlar aracılığıyla ilişki kurmasından dolayı kendilerinin bir robottan farksız olduğunu düşünmeleri, aidiyet duygusunu zamanla yitirmeleri ve 'kimliksizlik' gibi tanımlamalar yapmalarıdır. Tele çalışma, görüşmelerden de anlaşıldığ 1 üzere her zaman görüntülü görüşmelerle yürütülmemekte kimi zaman sadece sesli telefon görüşmeleri ya da epostalar aracılığıyla da gerçekleştirilmektedir. Bu durumda da kişilerin kendilerine söylenilen işleri yapıp teslim etmesi söz konusu olmaktadır. Toplum içinde kendini; "bir paravanın arkasına saklanmış ve bir gölge gibi işleri gören kişi” olarak tanımlamak; bireyin sosyalizasyon sürecine zarar veren bir olgu olarak karşımıza çıkabilmektedir.

Yapılan görüşmelerde, iş kollarının uygun olması durumunda haftada belirli günlerde tele çalışmaya imkân verecek uygulamaların geliştirilmesinin, çalışan açısından birçok sıkıntıyı ortadan kaldıracağı sonucuna ulaşılmıştır. Böylece bireyler hem esnek çalışmanın firsatlarını yaşayabilecek hem de bir tecrit durumu yaşamayacaklardır.

Özellikle resmî tatiller öncesi ya da sonrasında arada kalan günlerde bu imkânın sunulmasının hem işlerin aksamamasını sağlayacağı hem de çalışanların aile ilişkilerine olumlu katkı yapacağı düşünülmektedir. Tele çalışma konusunda bir başka öneri, çalışanların işe gitmesi durumunda ödeme aldıkları bir kalem olan yol masrafları yerine tele çalışanların faturalarına destek olabilmek adına fatura ödemeleri gözden geçirebilir bir durum olarak karşımıza çıkmaktadır.

\section{Kaynakça}

Aksoy, B. (2012). Bilgi teknolojileri ve yeni çalışma şekilleri. Ege Akademik Bakış, 12(3), 401-414.

Apgar, M. (2001). Alternatif işyeri. Harvard Business Review (İş ve Yaşam Dengesi). (Çev: İbrahim Bingöl). İstanbul: MESS Yayınları.

Baykal, R. (2003). Çalışma hayatında esneklik arayışları. Kahramanmaraş Sütçü İmam Üniversitesi, Sosyal Bilimler Enstitüsü, İşletme Anabilim Dalı. Yayımlanmamış Yüksek Lisans Tezi. Kahramanmaraş.

Birsel, M. (2007). İnsan kaynakları uygulamalarında etik yaklaşımlar. S. Tevrüz (Yay. haz.), İş hayatında etik içinde (s. 151178). İstanbul: Beta Basım Yayın.

Blomeyer, W. (1994). Almanya'da istihdam ilişkilerinin esnekleştirilmesi yönünde denemeler. Çalı̧̧ma Hayatında Esneklik Semineri. Yaşar Eğitim ve Kültür Vakfi, İzmir.

Braverman, H. (2008). Emek ve tekelci sermaye. (Çev: Çiğdem Çidamlı). İstanbul: Kalkedon Yayınları.

Butler, E. S., Aasheim, C., Williams S. (2007). Technical opinion: Does telecommuting 1mprove productivity? Communication of the ACM, 50(4), 101-103.

Castells, M. (2005). Ağ Toplumunun Oluşumu. İstanbul: İstanbul Bilgi Üniversitesi Yayınları.

Drucker, P. F. (2001). Beyond the information revolution. A. Giddens (Yay. haz.), Sociology, Intruductory Readings içinde. Cambridge: Cambridge: Polity Press.

Eyrenci, Ö., Bakırcı, K. (2000). Dünyada ve Türkiye'de evde çalışma ve eve iş verme. İstanbul: İTO Yayınları.

Feenberg A. (1990). Post-industrial discourses. Theory and Society. 19(6), 709-710.

Fu, M., Kelly, J. A., Clinch, J. P., King, F. (2012). Environmental policy implications of working from home: Modelling the impacts of land-use, Infrastructure And Sociodemographics. Energy Policy, 47, 416-423.

Grint, K. (1998). The sociology of work. USA: Blackwell Publishing.

Guthrie, R., Pick, J. (1997). Teleworking Ethics. AMCIS 1997 Proceedings. https://aisel.aisnet.org/amcis1997/263 adresinden erişildi.

Guthrie, R. (1997). The Ethics of Telework. Information Systems Management, 14(4), 29-32.

Gökbayrak, Ş. (2005). Esnek istihdam stratejileri ve iş sağlı̆̆ 1 ve güvenliği açısından ortaya çıkan riskler. Genel-IŞs Emek Araştırma Dergisi, 2, 63-70.

Haddon, L. (1998). The experience of teleworking: A view from the home, teleworking: International perspectives. From telecommuting to the virtual organisation. London: Routledge.

Harrison, N. (1998). Teleworking from home, http://www.ariadne.ac.uk/issue17/teleworking/ adresinden erişildi.

Harvey, D. (1999). Postmodernliğin durumu. (Çev. Sungur Savran), İstanbul: Metis Yayınları.

Hill, E. J., Ferris, M., Martinson, V. (2003). Does it matter where you work? A comparison of how three work venues (traditional office, virtual office, and home office) influence aspects of work and personal/family life, Journal of Vocational Behavior. 63(2), 220-241. 
Hueck, G. (1994). Almanya'da çalışma sürelerinin esnekleştirilmesine yönelik çalışmalar. (Çev: Öner Eyrenci). Çalışma hayatında esneklik, İzmir: Yaşar Eğitim ve Kültür Vakfı Yayınları.

Jackson, P. (1999) From New Desings and New Dynamics. P. Jackson (Yay. haz.), virtual working, social and organisational dynamics içinde (s. 1-16). London and New York: Routledge.

Kumar, K. (2004). Sanayi sonrası toplumdan post-modern topluma. (Çev: Mehmet Küçük). Ankara: Dost Kitabevi Yayınları.

Kurland, N. B., Bailey, D. E. (1999). Telework: The Advantages And Challenges Of Working Here, There, Anywhere And Anytime. Organizational Dynamics, 28(2), 53-68.

Naktiyok, A., İşçan, Ö. F. (2003). İşgörenlerin evden çalışmaya ilişkin tutumları: Bireysel özellikler ve iş sürükleyicileri açısından bir uygulama, Akdeniz İI.I.B.F. Dergisi, 6, 53-72.

Neumark, D., Reed, D. (2002). Employment relationship in the new economy. NBER Working Paper. No. 8910, April, 1-31.

Ongan, N. T. (2004). Esneklik yaklaşımının istihdam hacmi acısından değerlendirilmesi. Çalışma ve Toplum. 2004/3, 123-142.

Perez, M. P., Sanchez, A.M., De Luis Carnicer, M.P. (2002). Benefits and barriers of telework: Perception differences of human resources managers according to company's operations strategy, Technovation. 22, 775-783.

Primo, N. (2003). Gender issues in the information society. Paris: UNESCO publications for the world summit on the information society.

Savcı, İ. (1999). Çalışma yaşamı ile çalışma dışı yaşam alanlarının iliş̧isi üzerine kuramsal yaklaşımlar. Ankara Üniversitesi Siyasal Bilgiler Fakültesi Dergisi, 54(4), 146-166.

Sennett, R. (2011). Karakter aşınması. İstanbul: Ayrıntı Yayınları.

Stephen, P. R., Coulter, M. (2001). Management. New Jork: Prentice Hall.

Şen, S. (2000). Esnek Üretim ve Esnek Çalışma. TÜHIS. C. 15-16, 1-6, 24-55.

Tanılır, M. N. (2002). Internet suçları ve bireysel mahremiyet. Ankara: Liberte Yayınları.

Watson T. J., (2004). Sociology, work and industry. USA: Routledge \& Kegan Paul Publication.

Yalınpala, J. (2003). Küreselleşmenin emek piyasası ve istihdam üzerindeki etkileri. Küreselleşme: iktisadi yönelimler ve sosyopolitik karşıtlıklar. (Der. Nuri Alkan Soyak), İstanbul: Om Yayınevi.

Yavuz, A. (1995). Esnek çalışma ve endüstri ilişkilerine etkisi. Ankara: Türk Tarih Kurumu Basımevi.

Yıldırım, A., Şimşek, H. (2008). Nitel araştırma yöntemleri, Ankara: Seçkin Yayıncılık.

Yazıcıŏlu, Y. ve Erdoğan, S. (2004). SPSS uygulamalı bilimsel araştırma yöntemleri. Ankara: Detay Yayıncılık. 